九州大学学術情報リポジトリ

Kyushu University Institutional Repository

Influence of measurement principle on total hemoglobin value

林，啓介

http://hdl. hand le. net/2324/4474885

出版情報：九州大学，2020，博士（学術），課程博士 バージョン：

権利関係 : 


\title{
Influence of measurement principle on total hemoglobin value
}

Keisuke Hayashi ${ }^{1,2}$, Takashi Hitosugi ${ }^{1 *}$, Yoshifumi Kawakubo ${ }^{1}$, Norihisa Kitamoto ${ }^{1}$ and Takeshi Yokoyama ${ }^{1}$

\begin{abstract}
Background: Total hemoglobin ( $\mathrm{tHb}$ ) measurement is indispensable for determining the patient's condition (hemorrhagic vs. ischemic) and need for blood transfusion. Conductivity- and absorbance-based measurement methods are used for blood gas analysis of tHb. For conductivity-based measurement, $\mathrm{tHb}$ is calculated after converting blood conductivity into a hematocrit value, whereas absorbance measurement is based on light absorbance after red blood cell hemolysis. Due to changes in plasma electrolytes and hemolysis, there is a possibility that conductivity- and absorbance-based measurement methods may cause a difference in $\mathrm{tHb}$.
\end{abstract}

Methods: In this study, test samples with controlled electrolyte changes and hemolysis were created by adding sodium chloride, distilled water or hemolytic blood to blood samples collected from healthy volunteers, and tHb values were compared between both methods.

Results: Conductivity-based measurement revealed reduced tHb value (from 15.49 to $13.05 \mathrm{~g} / \mathrm{dl}$ ) following the addition of $10 \%$ sodium chloride, which was also reduced by the addition of hemolysate. Conversely, the addition of distilled water significantly increased $\mathrm{tHb}$ value than the expected value. In the absorbance method, there was no significant change in tHb value due to electrolyte change or hemolysis.

Conclusions: We have to recognize unexpected conductivity changes occur at all times when tHb is measured via conductivity- and absorbance-based measurement methods. The absorbance method should be used when measuring $\mathrm{tHb}$ in patients with expected blood conductivity changes. However, when using this method, the added contribution of hemoglobin from hemolytic erythrocytes lacking oxygen carrying capacity must be considered. We recognize that discrepancy can occur between conductivity- and absorbance-based measurement methods when thb is measured.

Keywords: Total hemoglobin (tHb), Blood gas analysis device, Absorbance measurement, Conductivity measurement

\section{Background}

The total hemoglobin (tHb) value in red blood cells (RBCs) is a critical measure of blood oxygen transport capacity. When the hemoglobin value abruptly declines due to hemorrhage, oxygenation of the tissue cannot be properly maintained. Thus, the accurate measurement of $\mathrm{tHb}$ in emergency, surgery and intensive care settings is vital for understanding the current condition of patients with hemorrhage and is the most important indicator for

\footnotetext{
*Correspondence: hitosugi.takashi.724@m.kyushu-u.ac.jp

${ }^{1}$ Department of Dental Anesthesiology, Faculty of Dental Science, Kyushu

University, 3-1-1 Maidashi, Higashi-ku, Fukuoka 812-8582, Japan

Full list of author information is available at the end of the article
}

determining the need for transfusion of $\mathrm{RBC}$ products. We previously experienced a case in which hemolysis was observed after infusion or transfusion during veno-arterial extracorporeal membrane oxygenation (VA ECMO), and tHb value differed between conductivity [1] and absorbance [2] measurement methods. Thus, the tHb value did not match the patient's condition and treatment status.

The conductivity method measures the potential difference between two electrodes in a blood specimen. This potential difference is converted into a hematocrit value according to the characteristic inverse relationship between conductance and the number and size of RBCs in the specimen, and $\mathrm{tHb}$ is subsequently calculated. So, the

() The Author(s). 2020 Open Access This article is licensed under a Creative Commons Attribution 4.0 International License, which permits use, sharing, adaptation, distribution and reproduction in any medium or format, as long as you give appropriate credit to the original author(s) and the source, provide a link to the Creative Commons licence, and indicate if changes were made. The images or other third party material in this article are included in the article's Creative Commons licence, unless indicated otherwise in a credit line to the material. If material is not included in the article's Creative Commons licence and your intended use is not permitted by statutory regulation or exceeds the permitted use, you will need to obtain permission directly from the copyright holder. To view a copy of this licence, visit http://creativecommons.org/licenses/by/4.0/. The Creative Commons Public Domain Dedication waiver (http://creativecommons.org/publicdomain/zero/1.0/) applies to the data made available in this article, unless otherwise stated in a credit line to the data. 
conductivity results regard as the hematocrit. However, this method may be influenced by changes in electrolyte concentration in the absence of $\mathrm{tHb}$ changes; therefore, there is doubt concerning the reliability of this method in patients with electrolyte imbalances due to the patient's condition and the treatment. We should recognize that discrepancy will occur between hematocrit value and tHb in the conductivity method. Alternatively, the absorbance method is not influenced by electrolytic concentration in the absence of $\mathrm{tHb}$ changes. However, in the absorbance measurement method, tHb is measured via light absorbance after RBCs are completely hemolysed by ultrasonic waves, so it is impossible to distinguish between hemoglobin from hemolytic RBCs and that released from functional RBCs.

Thus, both measurement methods have advantages and limitations in the clinical setting. Therefore, to examine how conductance- and absorbance-based methods are influenced by electrolyte balance changes and hemolysis, we compared $\mathrm{tHb}$ values of blood samples collected from healthy adult volunteers with controlled changes conferred by adding a $10 \%$ solution of sodium chloride $(\mathrm{NaCl})$ solution, distilled water (DW) or hemolytic RBCs.

\section{Methods}

\section{Sample, setting and interventions}

Blood samples were collected from five healthy adult male volunteers (mean age: $33.6 \pm 7.40$ years, mean height: $172.6 \pm 5.26 \mathrm{~cm}$, mean weight: $72.1 \pm 3.0 \mathrm{~kg}$ ), They met the standard blood test of WHO classification (Red blood cell count: $3.87-5.2 \times 10^{12} / \mathrm{L}$, White blood cell count: $3.3-8.6 \times$ $10^{9} / \mathrm{L}$, Platelets: $158-348 \times 10^{9} / \mathrm{L}, \quad \mathrm{Hb}: \quad 13.7-16.8 \mathrm{~g} / \mathrm{dl}$, Hematocrit: 37.4-48.6\%, Mean corpuscular volume: 87.2
$104.2 \mathrm{fl}$, Mean hemoglobin content: $29.2-35.3 \mathrm{pg}$, Mean hemoglobin concentration: 32.0-35.0\%) without complications, anemia and hemodyscrasia who provided informed consent to participate in this study. Approximately $18 \mathrm{~mL}$ blood per person was collected from the cubitus vein in a vacuum blood vessel using a 21-gauge needle. $\mathrm{NaCl}$ solution, DW and hemolysed blood were added to the collected blood from volunteers to create three models, namely, high conductivity, low conductivity and hemolysis, respectively (Fig. 1). Blood tHb value was measured using an ABL $77^{\circ}$ (conductivity 77) and ABL $725^{\circ}$ (absorbance 725) system for conductivity- and absorbance-based measurements, respectively (both instruments from Radiometer K.K., Tokyo, Japan). For the conductivity change model, $10 \% \mathrm{NaCl}$ (Otsuka saline 10\% solution; Otsuka Pharmaceutical Co., Ltd., Tokyo, Japan) was added to increase the serum $\mathrm{Na}^{+}$ level by 30 and $60 \mathrm{mEq} / \mathrm{L}$ (Table. 1), whereas $\mathrm{DW}\left(\mathrm{PL}^{\circ}\right.$; Fuso Pharmaceutical Industries, Ltd., Tokyo) was added to reduce the serum $\mathrm{Na}^{+}$level by 10 and $20 \%$ (Table. 2). DW was added slowly while mixing the sample to prevent hemolysis. Addition of DW did not lead to hemolysis and change mean RBC volume. All samples were stirred to ensure mixing. For the hemolysis model, the collected blood was completely hemolysed by freeze-thawing, and a proportion of this was added to untreated sample. Complete hemolysis was visually confirmed via light microscopy (Table. 3). For the absorbance change model, the clinical spectrophotometer has a measurement range of 478 to 672 $\mathrm{nm}$ and uses 128 wavelengths.

$\mathrm{tHb}$ and $\mathrm{Na}^{+}$levels were measured thrice in each specimen, and each specimen was measured using both methods and $\mathrm{tHb}$ corrected for dilution ratio.

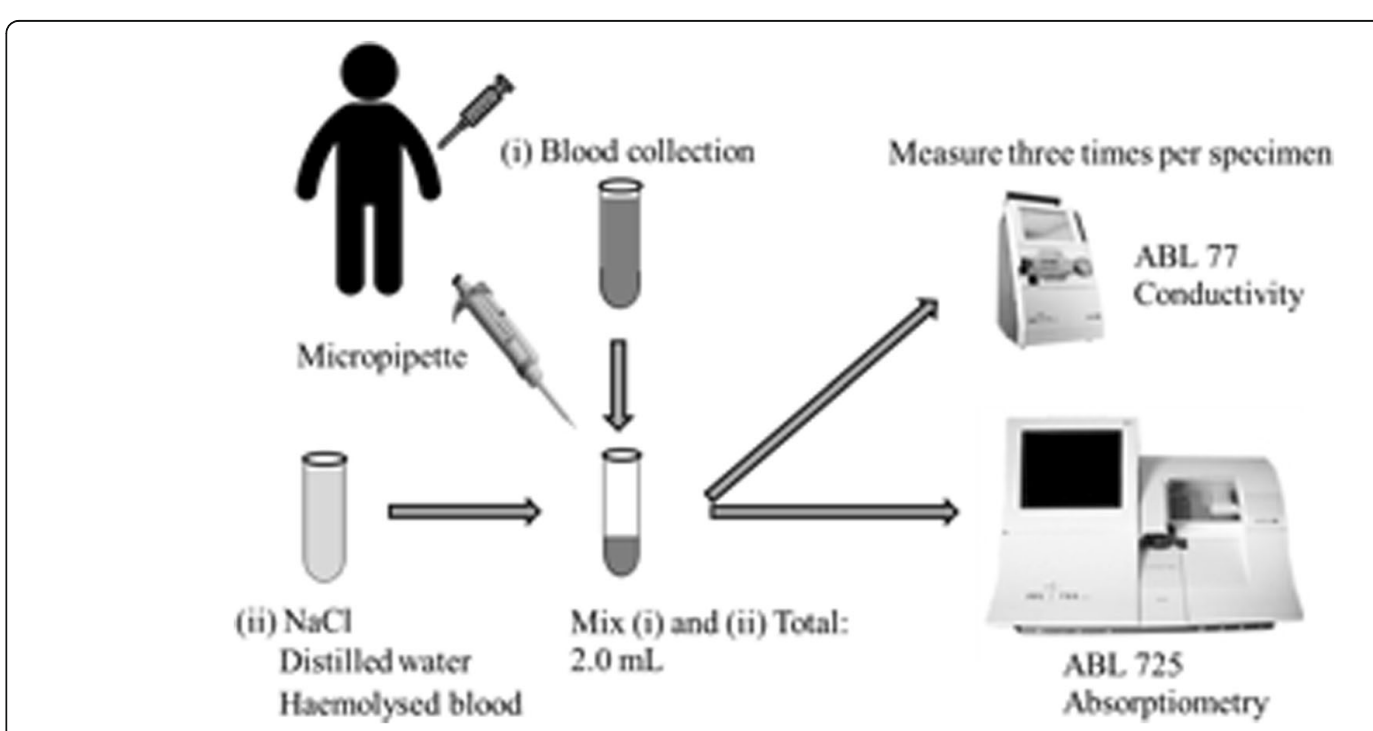

Fig. 1 Measured using conductance and absorbance measurements. $\mathrm{NaCl}$ solution, DW and hemolysed blood were added to the collected blood 
Table 1 High conductivity model

\begin{tabular}{llll}
\hline $10 \% \mathrm{NaCl}$ & Blood volume $(\mathrm{ml})$ & $10 \% \mathrm{NaCl}(\mathrm{ml})$ & Total $(\mathrm{ml})$ \\
\hline $30 \mathrm{mEq} / \mathrm{L}$ added & 1.975 & 0.025 & 2.00 \\
$60 \mathrm{mEq} / \mathrm{L}$ added & 1.950 & 0.050 & 2.00 \\
\hline
\end{tabular}

High conductivity model. $10 \% \mathrm{NaCl}$ was added to increase the serum $\mathrm{Na}+$ level by 30 and $60 \mathrm{mEq} / \mathrm{L}$

\section{Statistical analysis}

All measurements are expressed as mean \pm standard deviation, and Student's $t$-test was used to compare values between the two measurement method groups and between each measurement method group and untreated controls. The level of significance $(P)$ was set at 0.05 (two-tailed)

\section{Results}

Mean $\mathrm{tHb}$ values of control (untreated) blood samples did not differ between conductivity 77 and absorbance $725(15.49 \pm 1.18$ vs. $15.37 \pm 0.09 \mathrm{~g} / \mathrm{dl}, P>0.05)$. Mean tHb values significantly differed between conductivity and absorbance measurement methods for both the + $30 \mathrm{mEq} / \mathrm{ml} \mathrm{Na}^{+}(14.04 \pm 1.13$ vs. $15.53 \pm 1.02 \mathrm{~g} / \mathrm{dl}, P<$ $0.05)$ and $+60 \mathrm{mEq} / \mathrm{l}(13.05 \pm 0.97$ vs. $15.20 \pm 0.91 \mathrm{~g} / \mathrm{dl}$, $P<0.05)$ samples. Compared with untreated control samples, the conductivity 77 yielded lower tHb values, whereas the absorbance 725 showed no difference in tHb values (Fig. 2). Thus, conductivity-based but not absorbance-based tHb measurements were sensitive to increased sample electrolyte concentration. Conductivity 77 and absorbance 725 values also significantly differed for the $10 \%(14.53 \pm 1.02$ vs. $14.06 \pm 0.94 \mathrm{~g} / \mathrm{dl}, P<0.05)$ and $20 \%(13.41 \pm 1.02$ vs. $12.46 \pm 0.89 \mathrm{~g} / \mathrm{dl}, P<0.05)$ dilution samples. Compared with untreated control samples, conductivity 77 yielded elevated tHb values and the magnitude of elevation increased with dilution $(20 \%>$ $10 \%$ ), whereas absorbance 725 showed no difference in tHb values (Fig. 3). Conductivity 77 and absorbance 725 values also differed for all hemolysis samples (10\%: $15.02 \pm 1.04$ vs. $15.56 \pm 0.87 \mathrm{~g} / \mathrm{dl}, 50 \%: 13.81 \pm 0.77$ vs. $16.04 \pm 1.08 \mathrm{~g} / \mathrm{dl}, 90 \%: 12.45 \pm 0.88$ vs. $15.91 \pm 1.15$ and 100\%: $12.09 \pm 0.87$ vs. $15.96 \pm 0.95 \mathrm{~g} / \mathrm{dl}$; all $P<0.05$ ) Compared with untreated controls samples, tHb values were progressively reduced by the addition of hemolytic RBCs as measured using conductivity 77 , and the values also differed as measured using absorbance 725 (Fig. 4). Serum $\mathrm{Na}^{+}$levels were approximately equivalent among

Table 2 Low conductivity model

\begin{tabular}{llll}
\hline Distilled water & Blood volume $(\mathrm{ml})$ & Distilled water $(\mathrm{ml})$ & Total $(\mathrm{ml})$ \\
\hline $10 \%$ added & 1.80 & 0.20 & 2.00 \\
$20 \%$ added & 1.60 & 0.40 & 2.00
\end{tabular}

Low conductivity model. DW was added to reduce the serum $\mathrm{Na}+$ level by 10 and $20 \%$ corresponding samples according to conductivity 77 and absorbance 725 measurements (Fig. 5).

\section{Discussion}

Conductivity 77 is a portable blood gas measurement device that operates on the basis of the conductivity principle. The measurement duration is short, and manipulation and maintenance are easy, making conductivity 77 optimal for use in emergencies. The same holds true for the absorbance 725 device. There were no differences between conductivity 77 and absorbance 725 in $\mathrm{pH}, \mathrm{pCO} 2, \mathrm{pO} 2, \mathrm{Na}^{+}, \mathrm{K}^{+}, \mathrm{Ca}^{2+}$, and hematocrit, suggesting sufficient reliability. The conductivity method measures the potential difference between two electrodes in a blood specimen. This potential difference is converted into a hematocrit value according to the characteristic inverse relationship between conductance and the number and size of RBCs in the specimen, and tHb is subsequently calculated. So, the conductivity results regard as the hematocrit. However, this method may be influenced by changes in electrolyte concentration in the absence of tHb changes; therefore, there is doubt concerning the reliability of this method in patients with electrolyte imbalances due to the patient's condition and the treatment. We should recognize that discrepancy will occur between hematocrit value and $\mathrm{tHb}$ in the conductivity method. Conductivity 77 is also useful compared with absorbance measurement and centrifugal separation methods. However, a dissociation between conductivityand absorbance-based hematocrit measurements has been reported [3-5]. Using the conductivity-based method, the measured hematocrit value is lower than the absorbance-based value because of the influence of dilution by infusion, cardiopulmonary bypass and electrolyte concentration [6]. Alternatively, we found that absorbance-based measurements did not differ between control samples (untreated) and samples with experimentally altered electrolyte levels and pre-existing hemolysis (after correcting for dilution).

The conductivity measurement method uses two electrodes that are in direct contact with the specimen blood. A current is passed between the electrodes, and the potential difference is measured. The potential difference varies linearly with conductance, which depends on cell density and electrolyte concentration. However, four factors affect conductance-based measurements aside from cell density/size: however, conductance-based measurements are affected by four factors: electrolyte concentration, protein concentration, osmotic pressure and hemolysis $[7,8]$.

Blood is a viscous fluid that contains plasma, cells and proteins. Electrolytes account for most of the conductivity of plasma, whereas $99 \%$ of the cells are nonconductive RBCs. The measurable $\mathrm{Na}^{+}$level of the conductivity 
Table 3 Hemolysed blood model

\begin{tabular}{llll}
\hline Hemolysed blood rate(\%) & Blood volume $(\mathrm{ml})$ & Hemolysed blood volume $(\mathrm{ml})$ & Total $(\mathrm{ml})$ \\
\hline 10 & 1.80 & 0.20 & 2.00 \\
50 & 1.00 & 1.00 & 2.00 \\
90 & 0.20 & 1.80 & 2.00 \\
100 & 0.00 & 2.00 & 2.00 \\
\hline
\end{tabular}

77 instrument ranges from 80 to $200 \mathrm{mmol} / \mathrm{l}$, and the tHb. value is calculated using $\mathrm{Na}^{+}$correction. In this study, the $\mathrm{tHb}$ value was reduced by elevated $\mathrm{Na}^{+}$ level (high conductance) and vice versa, suggesting that additional $\mathrm{Na}^{+}$causes errors in $\mathrm{tHb}$ measurement because $\mathrm{tHb}$ cannot be corrected even within the $\mathrm{Na}^{+}$measurement range of the conductivity 77 instrument.

\section{Strengths and limitations}

Proteins account for $1-7 \%$ of the plasma but are nonconductive. Conductivity 77 measures tHb by assuming that the protein concentration is constant. Therefore, in case of excess replacement fluid or low protein levels, the conductivity of blood is increased, which causes an error in tHb measurement [9]. Total osmotic pressure is conferred by crystalloid (mainly from $\mathrm{Na}^{+}$) and colloid (mainly from albumin) osmotic pressures. In high osmotic pressure, RBCs volume is reduced. Conversely, low osmotic pressure results in RBCs swelling. In accordance with the principle of the conductivity measurement method, an error may occur because tHb measurement is inversely proportional to RBCs volume. Hemolysis occurs when RBCs (nonconductors) rupture. If protein concentration changes but nothing else does, $\mathrm{tHb}$ would change falsely. As the proportion of hemolytic RBCs increases, that of plasma increases. Therefore, our results also suggest that the electrical conductivity of blood increases and measured $\mathrm{tHb}$ value decreases with hemolysis.

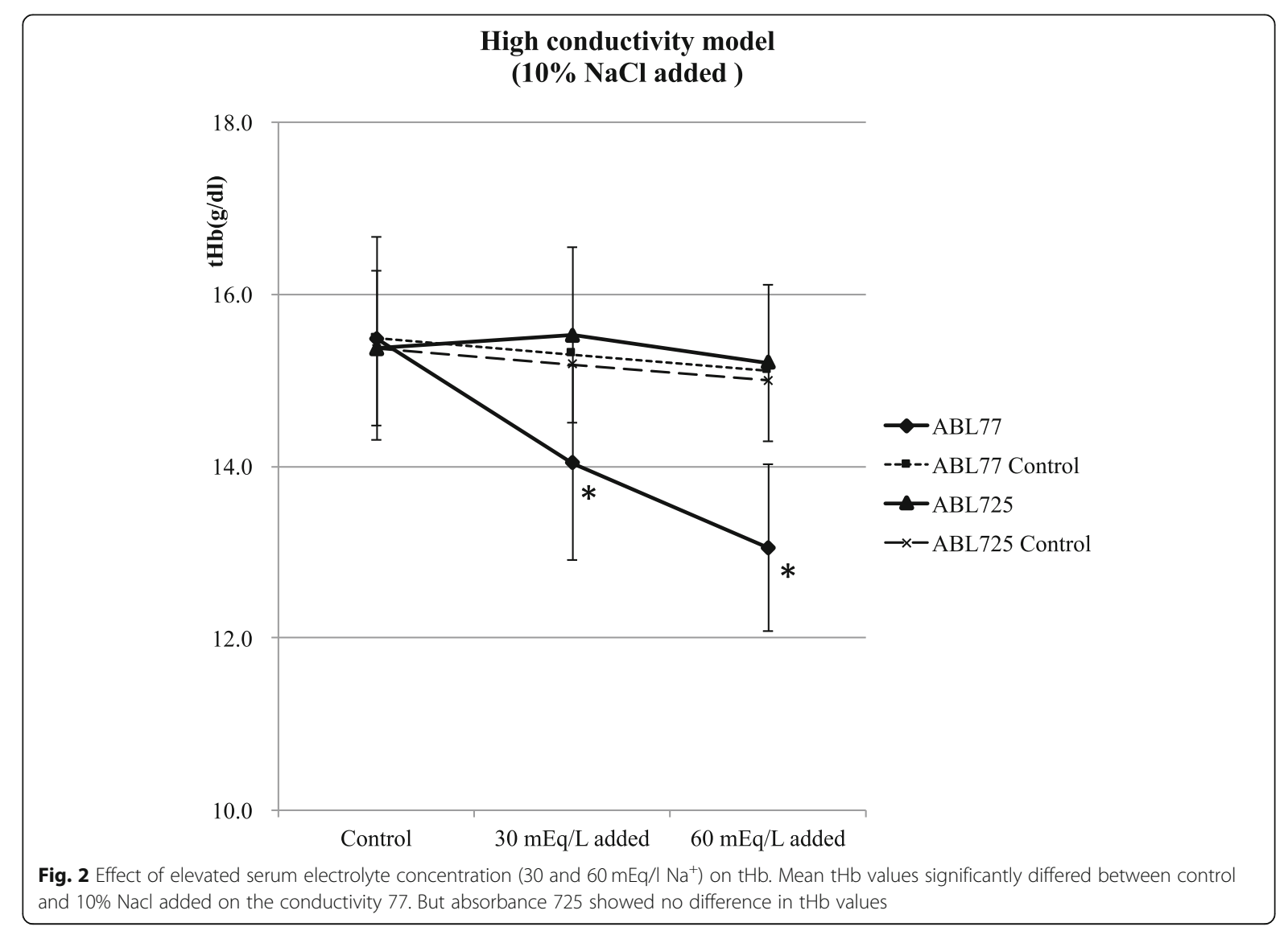




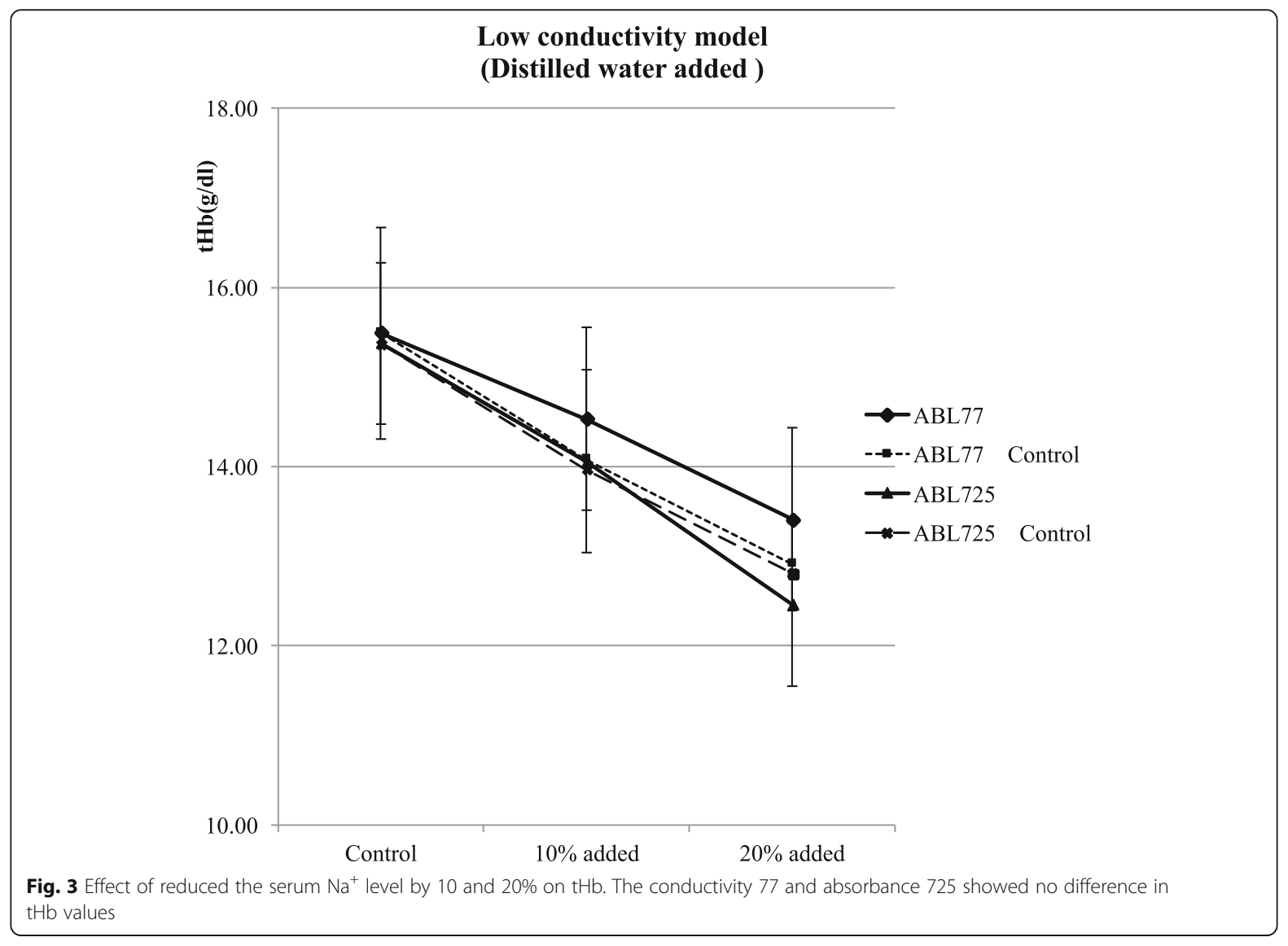

The absorbance 725 is a desktop-type blood gas measurement device that is based on sample light absorbance. In this case, $\mathrm{tHb}$ value is measured according to hemoglobin concentration and optical path length (which are in proportion). Prior to measurement, ultrasonic vibration is applied to completely hemolytic RBCs in the specimen. Therefore, $\mathrm{Hb}$ from hemolytic RBCs is added to that from functional RBCs. In our study, electrolytes and hemolysis did not affect absorbance-based $\mathrm{tHb}$ measurements. However, fetal hemoglobin (HbF) has been reported to have molecular structure different that is from that of adult hemoglobin, and errors occur in $\mathrm{HbF}$ measurement when the total bilirubin concentration is high $[10,11]$. By the influence of bilirubin, measurement error occurs on the specimen light absorbance in the wavelength band $478-500 \mathrm{~nm}$. Due to the characteristic difference in the molecular structure between adult $\mathrm{Hb}(\mathrm{HbA})$ and $\mathrm{HbF}$, the light absorbance of $\mathrm{HbA}$ and $\mathrm{HbF}$ are different in the wavelength band of 450 to $500 \mathrm{~nm}$. And, $\mathrm{HbF}$ is measured from the difference of absorbance $[11,12]$. In severe jaundice the $\mathrm{HbA}$ and $\mathrm{HbF}$ value measured with the absorbance method are not identical with the real blood concentration of the hemoglobin. $\mathrm{HbA}$ and $\mathrm{HbF}$ tend to be higher than normal values. In absorbance 725, a bilirubin of $20 \mathrm{mg} / \mathrm{dL}$ can produce an artifact in $\mathrm{HbF}$ of $0.5 \mathrm{~g} / \mathrm{dL}$ [13]. Both instruments also measure $\mathrm{Na}^{+}$, but the measurement principle is identical, so there were no differences in the measured values between these instruments.

Based on these findings, when excessive replacement fluid or electrolyte abnormality is suspected, an absorbance-based tHb measurement method should be used. However, absorbance-based measurements should be corrected for $\mathrm{Hb}$ from hemolytic RBCs to obtain a better estimate of the blood oxygen carrying capacity.

\section{Conclusions}

Blood gas analysis devices use different principles for tHb measurement. Therefore, the characteristics of the measuring device must be chosen according to potential errors introduced by the pathological state or treatment. For patients suspected of having excessive replacement fluid or an electrolyte abnormality, blood conductivity changes are possible. In such patients, absorbance measurement should be performed while taking hemolysis and bilirubin levels into consideration. 


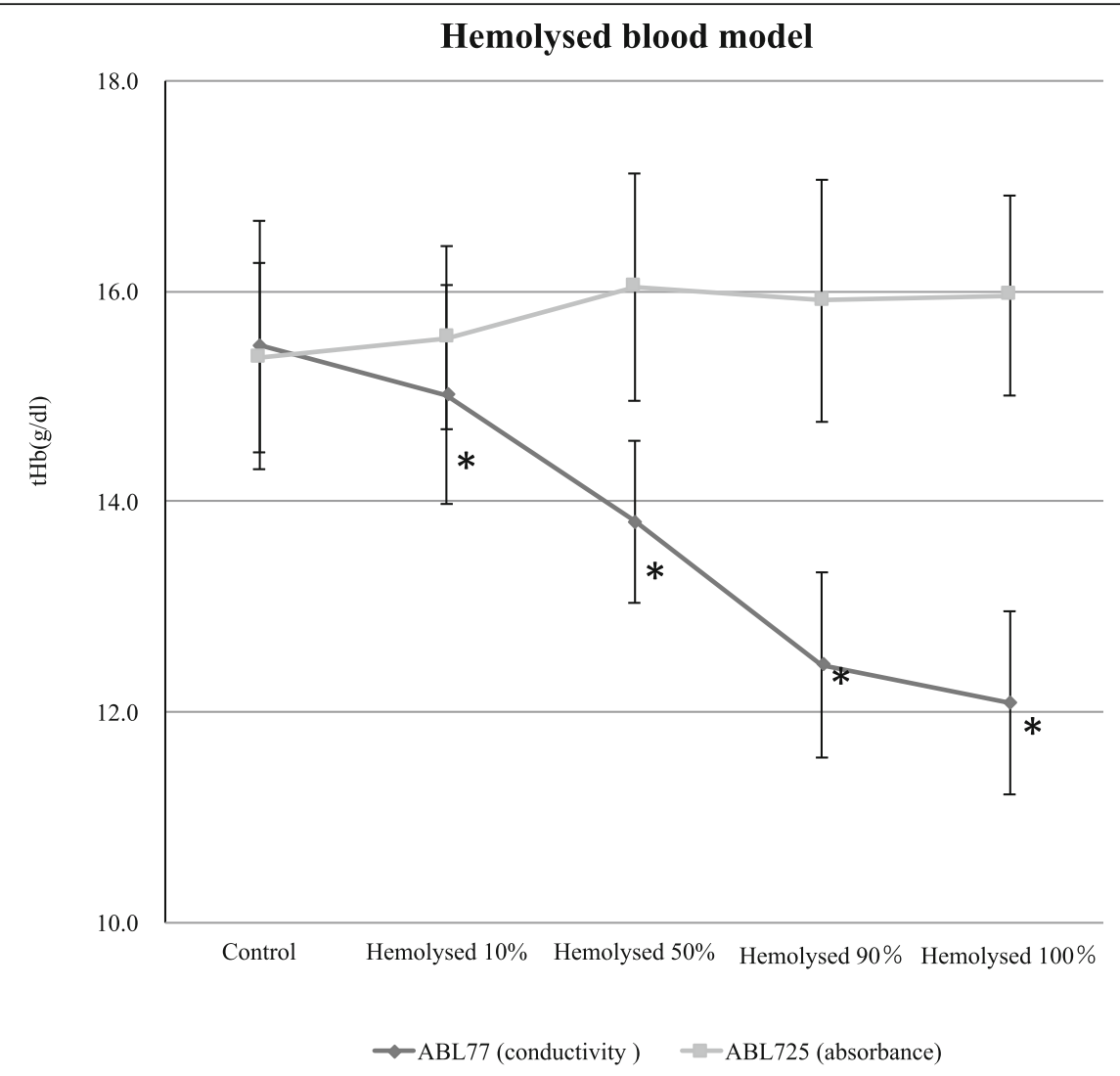

Fig. 4 Effect of the hemolysis model (10,50, 90 and 100\% haemolysed) on tHb. Mean tHb values significantly differed between the absorbance 725 and the conductivity 77

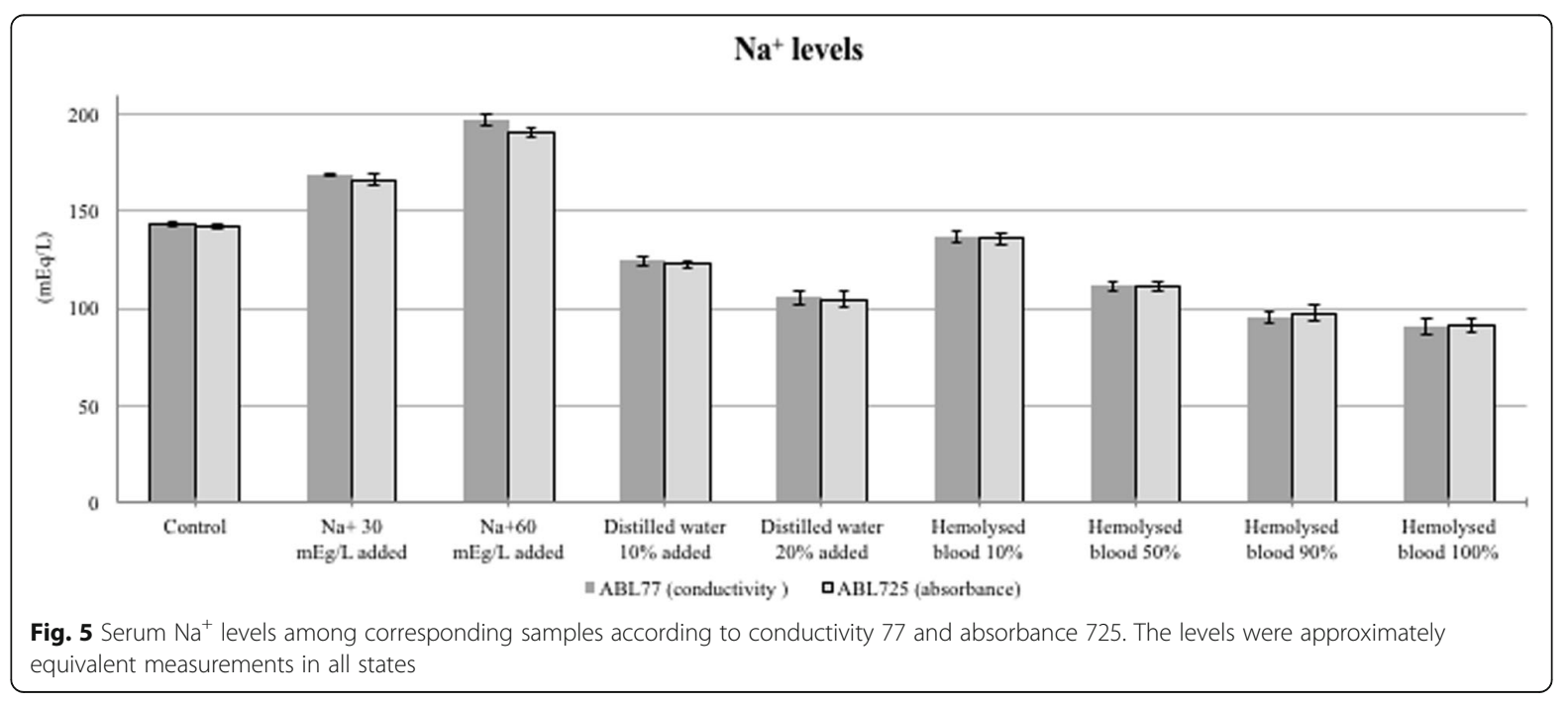




\section{Abbreviations}

tHb: The total hemoglobin; RBCs: Value in red blood cells; VA ECMO: Venoarterial extracorporeal membrane oxygenation; $\mathrm{NaCl}$ : Normal sodium

chloride; DW: Distilled water

\section{Acknowledgements}

Not applicable.

\section{Informed consent}

Informed consent was obtained from all individual participants included in the study

The content of this report was presented at the 33rd SSAI congress (10-12 June 2015, Reykjavik Iceland).

\section{Authors' contributions}

K.H.: Study design, data analysis, volunteer recruitment, data collection, and writing up of the paper. T.H.: data analysis and writing up of the paper. Y.K.: data analysis and writing up of the first draft of the paper. N.K.: writing up of the first draft of the paper. SS: data collection and writing up of the first draft of the paper. T.Y.: study design, data analysis and writing up of the first draft of the paper. All authors read and approved the final manuscript.

\section{Funding}

Not applicable.

\section{Availability of data and materials}

The datasets used and/or analysed during the current study are available

from the corresponding author on reasonable request.

\section{Ethics approval and consent to participate}

All included volunteers gave their oral and written informed consent. The study was approved by Okayama Saiseikai General Hospital Institutional Review Board. Approval date: 7 October 2014. Approval (No.: 141001).

\section{Consent for publication}

Not applicable.

\section{Competing interests}

All authors have no conflict of interest.

\section{Author details}

${ }^{1}$ Department of Dental Anesthesiology, Faculty of Dental Science, Kyushu University, 3-1-1 Maidashi, Higashi-ku, Fukuoka 812-8582, Japan. ${ }^{2}$ Clinical Engineering, Okayama saiseikai General Hospital, 2-25, Kokutai-cho, Kita-ku, Okayama 700-8511, Japan

Received: 8 May 2019 Accepted: 26 March 2020

Published online: 07 April 2020

\section{References}

1. Neelakantaswamy PS, Aspar KF, Rajaratnam A, Das NP. Conductimetric method of determining the hematocrit value of blood. Rev Sci Instrum. 1983;54:1186-90.

2. Ewing GW. Instrumental methods of chemical analysis. 5th ed. New York: McGraw-Hill; 1985.

3. Papadea C, Foster J, Grant S, Ballard SA, Cate JC 4th, Southgate WM, et al Evaluation of the i-STAT portable clinical analyzer for point-of-care blood testing in the intensive care units of a university children's hospital. Ann Clin Lab Sci. 2002:32:231-43.

4. Wu P, Morey TE, Harris NS, Gravenstein N, Rice MJ. Intravenous fluids cause systemic bias in a conductivity-based point-of-care hematocrit meter Anesth Analg. 2012:114:314-21.

5. Prichard JS, French JS, Alvar N. Clinical evaluation of the ABL-77 for point-ofcare analysis in the cardiovascular operating room. J Extra Corpor Technol. 2006;38:128-33.

6. Steinfelder-Visscher J, Weerwind PW, Teerenstra S, Pop GA, Brouwer RM. Conductivity-based hematocrit measurement during cardiopulmonary bypass. J Clin Monit Comput. 2007;21:7-12.

7. Briggs C, Kimber S, Green L. Where are we at with point-of-care testing in haematology? Br J Haematol. 2012;158:679-90.
8. Stott RA, Hortin GL, Wilhite TR, Miller SB, Smith CH, Landt M. Analytical artifacts in hematocrit measurements by whole-blood chemistry analyzers. Clin Chem. 1995;41:306-11.

9. Hopfer SM, Nadeau FL, Sundra M, Makowski GS. Effect of protein on hemoglobin and hematocrit assays with a conductivity-based point-of-care testing device: comparison with optical methods. Ann Clin Lab Sci. 2004;34: $75-82$.

10. Martens H. Multivariate calibration: quantitative interpretation of nonselective chemical data. Norwegian Institute of Technology; 1985.

11. Krzeminski A. Why correct for fetal hemoglobin in blood oximetry measurements? Radiometer publication info. No. 1992-3. Copenhagen: Radiometer Medical A/S; 1992.

12. Lampert $R$, Brandt $L$. The effect of hyperbilirubinemia on the measurement of oxygenated hemoglobin $(\mathrm{O} 2 \mathrm{Hb})$, carboxyhemoglobin $(\mathrm{COHb})$ and methemoglobin (MetHb) using multiwavelength oximeters in mixed venous blood. Anaesthesist. 1993;42:702-9.

13. Performance Characteristics. In: ABLTM700 Series Reference Manual. Ed. C. Copenhagen: Radiometer Medical A/S, 1999: Chapter 8, 13-22. Code No 989-312.

\section{Publisher's Note}

Springer Nature remains neutral with regard to jurisdictional claims in published maps and institutional affiliations.
Ready to submit your research? Choose BMC and benefit from:

- fast, convenient online submission

- thorough peer review by experienced researchers in your field

- rapid publication on acceptance

- support for research data, including large and complex data types

- gold Open Access which fosters wider collaboration and increased citations

- maximum visibility for your research: over 100M website views per year

At BMC, research is always in progress.

Learn more biomedcentral.com/submissions 